Is the Clean Development Mechanism delivering benefits to the poorest communities in the developing world?

\title{
Abstract
}

One of the international market based systems in operation to tackle climate change and help the worst-off reach sustainable development is the Clean Development Mechanism (CDM). The goal of this paper is to examine whether it respects principles of social and participatory justice. The first section describes the state of the climate as well as who is most vulnerable to its human impacts, and briefly discusses the resources dedicated to helping the worst-off adapt to climate change. Using criteria of social and participatory justice, the second section of this paper analyses whether the CDM is succeeding in its objective to assist the developing countries in pursuing sustainable development. Based on the findings of this analysis, the third section offers policy recommendations with a view to making the CDM more beneficial to the worst-off. The concluding section provides a summary of our main arguments and findings.

\section{Climate change and the worst-off}

Relative to 1990 levels, global greenhouse gas (GHG) emissions have risen by 30-39\%, with a 20\% rise in the period 2000-2010 (Le Quéré et al. 2009; UNEP 2012: 10). Although emissions from the developed countries have largely stabilized, emissions from emerging economies have doubled, mostly due to the growing international trade between industrialized and developing countries (Peters et al. 2009, 2012; IEA 2013: 27). Since it is estimated that emissions from the rising economies and the rest of non-OECD countries will top those of the 
developed countries in the third decade of this century, it is clear that these countries will have to participate in future mitigation efforts as well (van Vuuren et al. 2009).

Although the prevention of a $2^{\circ} \mathrm{C}$ global mean temperature rise (GMT) relative to preindustrial temperature has been adopted by the UNFCCC and the EU's climate policy (EC 2007; UN 1998), research shows that global GHG emissions remain on track to meet the IPCC's most fossil fuel intensive GHG emission scenario, which would constitute a $4^{\circ} \mathrm{C}$ temperature rise by 2100 (Betts et al. 2011: 80-2; Le Quéré et al. 2009; Peters et al. 2013: 5).

While global leaders have delayed negotiations on a new binding emissions treaty to 2015 , which would come into effect no sooner than 2020 (UNFCCC 2011), research indicates that global emissions would have to peak and decline before the end of this decade in order to have a reasonable chance of limiting global warming to $2^{\circ} \mathrm{C}$ GMT (Arnell et al. 2013: 2; den Elzen, et al. 2013: 496; Rogelj et al. 2012: 7; Rogelj et al. 2011: 414; Meinshausen et al. 2009: 1160). Rogelj and colleagues observe that, despite all the uncertainty regarding the geophysical, social and technological aspects of the climate problem, the dominant factor affecting the likelihood and costs of achieving the $2{ }^{\circ} \mathrm{C}$ objective is related to politics (2013a: 80).

Yet, whereas the politics that have to be agreed upon assume collective action, humanity is utterly divided in terms of wealth, health, living standards, education, and well-being (Biermann 2012: 6). Of particular relevance in this regard is the inequity inherent to climate change: although the poorest of the world are only responsible for a small part of the emissions that contribute to climate change, they (will) suffer most of the consequences (Costello et al. 2009: 1694; GHF 2009: 62). It is estimated that in the first half of the previous 
decade $98 \%$ of those affected in weather related disasters such as floods, droughts, and heat waves were members of developing countries (GHF 2009: 61). Furthermore, 60\% of the global population is vulnerable to climate change in socio-economic terms, and approximately 500 million people live in countries that are extremely vulnerable due to their geographical location and social circumstances (GHF 2009: 58, 60). Moreover, in the second half of the previous decade 235 million people were estimated to be seriously affected by climate change every year and 315,000 deaths were due to climate change (GHF 2009: 11). Projections for 2030 indicate that the number of affected persons will rise by 103\% (GHF 2009: 14).

The worst affected regions include the Sahara, the coastline of Eastern Africa, all of South Asia, and many small island states. Africa is the most vulnerable region, being home to 15 of the world's 20 most vulnerable countries. Those who directly rely on natural resources for their livelihoods such as farmers, fishermen, and low-wage earners will suffer income loss (GHF 2009: 58). It is estimated that by 2020 rain-fed agricultural yields in Africa could be reduced by 50\% (IPCC 2007: 50). Furthermore, half of the world's population lives in urban areas (IEA 2013: 88) and this amount is expected to rise to $70 \%$ by 2050 (Hoornweg et al. 2010: 16). In developing countries the share of urban populations is larger than in industrialized countries and the former will most likely bear $75 \%$ of the burdens of damages produced by climate change (Hoornweg et al. 2010: 4, 15).

Furthermore, climate change is already exacerbating chronic environmental threats and ecosystem losses are constraining livelihood opportunities, especially for the poor. Unless action is taken urgently, in South Asia and Sub-Saharan Africa in particular, future progress in human development will be threatened, effectively halting or even reversing decades of human development progress (UNDP 2013: 95). Even more alarming is the estimate that, in 
case of unabated environmental deterioration, ${ }^{1}$ the number of people living in extreme poverty would be 3.1 billion by 2050 (UNDP 2013: 95). In addition, $83 \%$ of displacements (119.8 million people) between 2008 and 2012 were triggered by climate- and weather-related hazards such as floods, storms and wildfires (IDMC 2013: 36; see also IPCC 2012, chapter 2). In 2012 alone, relative to 2011, the amount of displacements almost doubled to 32.4 million people, 98\% of which involved climate- and weather-related displacements (IDMC 2013: 11).

\section{The Clean Development Mechanism}

\subsection{Background}

One of the international economic systems in operation to tackle climate change is the Clean Development Mechanism (CDM) defined by Article 12 of the Kyoto Protocol (KP) (UN 1998). The detailed rules for its implementation and governance were adopted as part of the Marrakesh Agreements (UNFCCC 2001). The purposes of the CDM are: (1) to assist nonAnnex I Parties in achieving sustainable development; and (2) to assist Annex I Parties in achieving compliance with their quantified emission limitation and reduction commitments (UN 1998: 11).

The CDM is a market-based offsetting mechanism, which creates certified emission reductions (CERs). When countries (under the KP) or companies (under the EU Emission Trading System or ETS) invest in emissions saving projects in developing countries, the equivalent of the saved emissions results in CERs that project investors can trade or use to comply with mitigation pledges (European Parliament and the Council of the EU 2003).

\footnotetext{
${ }^{1}$ Environmental deterioration is defined as the effects of global warming on agricultural production, access to clean water and improved sanitation, and pollution (UNDP 2013: 95).
} 
Article 12 of the KP provides that the proceeds from certified project activities are to be used to cover administrative expenses as well as to assist developing countries to meet the costs of adaptation (UN 1998). The KP further states that the trading of emission reduction units shall be supplementary to domestic action for the purpose of meeting emission reduction commitments (UN 1998: 7, 15).

It is estimated that in 2011 the voluntary carbon market, to which the CDM is the chief contributor, delivered but 3.09\% of global climate funding (Buchner et al. 2011: 4). In 2010 the World Bank estimated that $\$ 75-100$ billion or $€ 57-77$ billion would be required by 2050 to support adaptation to the inevitable impacts of climate change on developing countries. However, the resources that have been committed to address mitigation and adaptation in these developing countries cover less than $5 \%$ of what will be needed annually by 2030 (Hoornweg et al. 2010: 5; Huhtale et al. 2010: 1).

Furthermore, although the rhetoric used in global climate change negotiations indicated that climate finance should be split 50:50 between adaptation and mitigation, in 2011 the scale stood at 5:95 (Buchner et al. 2011: 7). Since mitigation activities tend to have more private sector participation, the amount of private finance is triple that of public finance, with bilateral financial contributions exceeding multilateral ones (Buchner et al. 2011: 4-6).

The future of the CDM looks grim. The KP's first compliance period ended in 2012 and although a temporary successor was installed, entitled the Kyoto Protocol Second Commitment Period (KPII), the effort is futile in light of the 2015 negotiations. Because it omits the US and Canada and demands no binding reduction pledges from the emerging economies such as China, Brazil and India, the KPII now merely accounts for $15 \%$ of global 
emissions (Grubb 2013: 282). Furthermore, demand for CERs will only be powered by the EU ETS and the Australian emissions trading system (Grubb 2013: 281). Hence, CER prices keep track of the currently low EU ETS entitlement prices.

The EU ETS has been discussed from the perspective of two criteria of justice, effectiveness and fairness of the distribution of burdens (Dirix et al. 2013). The effectiveness of the EU ETS is threatened by the initial overallocation of emission entitlements, the banking of entitlements, and the use of offsetting credits, which have led to low carbon prices. The CDM is also prone to a number of additional problems, which include: the questionability of the claimed additionality of projects; the CDM's 'climatic equivalence' of surplus emissions of investors; the wrong incentive CDM offers to host countries; and the future vulnerability of the poorest countries and megacities when politically binding mitigation agreements are broadened so as to include non-OECD and Least Developed Countries (LDCs). In view of these flaws, offsetting in general can severely postpone emissions reductions and is thus ineffective.

\subsection{How just is the CDM?}

\subsubsection{The assessment of project contributions}

In this section the CDM will be evaluated from the perspective of participatory and social justice. This evaluation will be informed by available research on the governance as well as the effectiveness of the CDM, with a particular focus on research that uses the Project Design Documents (PDDs - i.e. the CDM application forms) as a primary source of information. 
Since no ex post verification is made of the ex ante sustainability claims made by the project developer, project contributions are merely assessed on the basis of project documentation (Crowe 2013: 63; du Monceau and Brohé 2011: 10; UNFCCC 2012a: 7). Moreover, it remains very difficult to assess project contributions to sustainable development (SD), since the Marrakesh Agreements stipulate that, in the absence of an internationally accepted definition of SD, it is the host country's prerogative to define the criteria of SD (UNFCCC 2001; 2012a: 10).

In practice this implies that a governmental Designated National Authority (DNA) evaluates PDDs against a set of pre-defined criteria, encompassing environmental and social aspects of sustainability (Boyd et al. 2009: 822; Olsen 2007: 62; Schneider and Grashof 2007: 4). However, in addition to intense competition between developing countries to attract CDM projects and the fact that there are little or no price premiums to be gained from investing in projects with higher contributions to $\mathrm{SD}$, the absence of international standards regarding $\mathrm{SD}$ results in a trade-off favouring the most cost-efficient emissions reduction projects, with the envisaged development opportunities taking a back seat to the emissions reduction aspect (du Monceau and Brohé 2011: 4; Gillenwater and Seeres 2011: 30; Lloyd and Subbarao 2009: 240; Olsen 2007: 67; Sutter and Parreño 2007: 76, 89). This trade-off could lead to a race-tothe-bottom in terms of SD standards, with non-Annex I countries undercutting each other to attract CDM investment, thereby fundamentally weakening the SD objective (Sutter and Parreño 2007: 76). Leaving the task of defining SD to the host country has arguably resulted in the concept usually being interpreted as 'economic growth' (Subbarao and Lloyd 2011: 1610). Moreover, available research indicates that CDM projects tend to deliver real emission reductions but do not contribute towards the host country's SD and the benefits accruing from CDM projects do not extend to poor people or local communities (Lloyd and Subbarao 2009: 
240; Sutter and Parreño 2007: 89). Some commentators therefore argue that the envisaged development opportunities appear to be more hypothetical than real (Lloyd and Subbarao 2009: 240). We will evaluate these observations in the light of principles of social and participatory justice.

\subsubsection{The CDM and social justice}

As mentioned earlier, the KP identified two goals for the CDM, the first of which is to assist non-Annex I countries in achieving SD. Since this goal especially focuses on the situation of those who (will) suffer most from climate change, it can be interpreted as caring for the worst-off. Although this remains a minimal and vaguely formulated distributive principle, we consider it to be a highly valuable guiding principle for climate policy instruments. Human development should include sustainable development since human development is inevitably flawed if it does not ensure that future generations can live fulfilling, healthy and educated lives (Peeters et al. 2013). Indeed, human development without sustainable development cannot be true human development (Neumayer 2010: 1; 2013: 562; Griggs et al. 2013: 306). Furthermore, although the CDM has no defined mission of delivering pro-poor benefits and has only been marginally successful in delivering them, there seems to be a consensus in the literature that the social dimension of SD should include poverty alleviation and equity as general criteria (Olsen 2007: 62).

It is widely acknowledged that the CDM has the potential to apply SD benefits at a community level and to direct these benefits to the poor (Crowe 2013: 75). Hence, in our view, the CDM has the formidable task of contributing to the alleviation of poverty through, inter alia, improving rural access to affordable 'clean' energy and investments to decrease 
vulnerability to climate change events and to increase climate resilience (Djanibekov et al. 2012; Mattsson et al. 2009; Tyler \& Moench 2012).

Since clean energy is necessary to reduce poverty, malnutrition and hunger, to improve health and literacy, and to enable especially women and children in the developing world to live better lives, it is considered to be a prerequisite of human development, and thus of sustainable development (Newell et al. 2011: 10; Sihori 2007: 102; Subbarao and Lloyd 2011: 1601-2). Access to clean and reliable energy can help improve standards of living and support sustainable livelihoods among rural and low-income urban populations, hence small-scale rural renewable energy projects seem to offer the best prospects for poverty alleviation under the CDM (Brunt and Knechtel 2005: 8). However, in 2010, 17\% of the global population did not have electricity access, with $85 \%$ of those without access living in rural areas and $87 \%$ in Sub-Saharan Africa and Southern Asia (World bank/IEA 2013: 91). In addition, the IEA (2013: 97) reports that the resilience of the energy system should be considered more explicitly since energy supply and transformation will be exposed to greater physical risks, which will drive up costs and impair energy supply liability in addition to accelerating the devaluation and deterioration of assets.

In 2012 the UN launched the 'Sustainable Energy for All' programme which aims to ensure universal access to modern energy services, double the global rate of improvement in energy efficiency, and double the share of renewable energy in the global energy mix by 2030 (UN 2012b). Rogelj and colleagues have examined these goals and found that the UN's initiative could provide multiple sustainability benefits such as eradicating poverty, improving energy security and public health, thereby instigating the process of climate protection (Rogelj et al. 2013b: 551). 
On the basis of evaluations of the PDDs submitted in the context of the CDM, the UNFCCC has concluded that the most prominent benefits claimed by project developers are the stimulation of the local economy through employment creation and poverty alleviation, followed by pollution reduction and the promotion of renewable energy and energy access. However, in all countries, social benefits tend to be cited less often than economic and environmental benefits. Furthermore, stimulation of the local economy, which includes job creation and poverty alleviation, was only explicitly present in $31 \%$ of the 2,864 examined projects in 2011 (UNFCCC 2012a: 19).

Sihori (2007: 105) has examined 65 PDDs for CDM projects in India and found that, although India is one of the most attractive non-Annex I countries for project development, social development is not at the heart of these projects as described by the applicants. She found that the potential of CDM projects to bring about observable reductions in rural poverty through the supplementation of agriculture income is doubtful on several grounds. The projects, Sihori argues, are limited in scope and have not been designed to directly benefit the agricultural sector. Neither do they offer benefits to landless households, which account for $48 \%$ of the 27 to $30 \%$ rural poor living in India today. Landless labourers can only expect an income rise if labour productivity is increased. However, without technical progress in agriculture, Sihori argues, labour productivity is unlikely to rise significantly (Sihori 2007: 98). As regards technology transfer, Das has examined 1000 PDDs and found that the contribution of the CDM to technology transfer can at best be described as minimal. Furthermore, given that the core objective of project participants is to generate CERs in the most cost-effective manner, decisions regarding the choice of technology and its source are bound to be subservient to this core objective (Das 2011: 28). 
Although the CDM has undoubtedly delivered improvements in energy efficiency in industrial firms and has thereby decreased production costs, rural poverty can only be affected by these improvements if the decrease in production costs can be transmitted to the products in the consumption basket of the rural poor (Sihori 2007: 104). Rural areas in particular need renewable energy since the distribution of fossil fuel energy is expensive and challenging. The limited physical access of rural households to electricity, as well as their low purchasing power, prevent the rural poor from having access to energy. The CDM is therefore deemed to play a critical role in making renewable energy and energy efficiency sustainable and replicable in developing and least developing countries (Subbarao and Lloyd 2011: 1602).

Yet, even the impact of increased power generation from renewable energy sources may not be very effective in improving the access of the rural poor to 'cleaner' energy. In addition, so far, only the better-off households in urban and rural areas are reaping the benefits of the power supply increase to the electricity grid resulting from renewable energy related CDM projects (Sihori 2007: 102). Sihori concludes that the socio-economic development potential of CDM projects in India is doubtful. Since the benefits of projects focussing on energy efficiency in industry remain largely 'firm-specific', these projects are unlikely to have an impact on rural poverty (Sihori 2007: 105). The CDM has thus far failed to direct energy investment to the poorest countries (Newell et al. 2011: 27) or communities.

Subbarao and Lloyd have examined 500 registered small-scale CDM projects in the fields of employment, migration, access to electricity, health, the use of local resources, local environment, and stakeholder perception. They found that CDM projects have generated: a highly beneficial impact on the utilisation of local resources; a medium to high score for 
socio-economic and human development impacts; a low to medium beneficial impact on employment generation for the local community and region; a low to medium score on stakeholder perception; low beneficial impacts on the local environment and community; a non-existent or very low level of beneficial impact on migration, community education, health and associated services, and electricity access; and a non-existent or very low beneficial impact on marginalised people in the community (Subbarao and Lloyd 2011: 1605-6).

In line with these findings, on the basis of an analysis of 16 CDM projects, Sutter and Parreño have found that $23 \%$ of all CERs were generated by projects owned by transnational private companies, with revenues flowing to people outside of the host country. A mere $0.3 \%$ of CERs created revenues were likely to flow to the poorer $50 \%$ of the host country population (Sutter and Parreño 2007: 84). As it seems unlikely that the benefits generated from these projects will 'trickle down' to reach the poor, these projects are unlikely to create any significant impact on the alleviation of rural poverty (Lloyd and Subbarao 2009: 242).

In a recent study, Crowe (2013) has examined 114 CDM projects for pro-poor benefits and found that $74 \%$ of CDM projects delivered no pro-poor benefits at the local community level, indicating that the project was not located in a high poverty area or that the documentation did not explicitly specify that the claimed benefits would be directed to the poor. Furthermore, $16 \%$ of the examined projects delivered only weak pro-poor benefits and a mere $10 \%$ of the projects were rated as 'moderate' or 'strong' (Crowe 2013: 66).

Some commentators argue that the CDM has served to mirror or even reinforce inequities in flows of finance, both between and within countries. Despite efforts by, for example, the Chinese government to steer investors toward the poorest parts of the countries, the wealthier 
regions in all three major CDM host countries (Brazil, India and China) are more likely to attract CDM projects (Newell 2009: 432). In short, the conclusion thus far seems to be that the CDM has not yet produced substantial benefits regarding poverty alleviation and that it has provided only limited support of sustainable social and economic development in host countries (Michaelowa and Michaelowa 2007: 3). Hence it fails to meet the requirements of social justice.

\subsubsection{The CDM and participatory justice}

After reviewing research on the impact of the CDM on the social justice dimension of sustainable development, this section will assess whether and to what extent the CDM complies with requirements of participatory justice. This assessment will be based on the application of three criteria, which up to a certain extent are related: inclusion; impartiality; and equality of opportunity (Page 2011: 53-4). Without attempting to be exhaustive, this assessment is informed by relevant literature on the PDDs of the CDM projects.

\subsubsection{Inclusion}

According to the principle of inclusion, the interests of all relevantly affected parties should be considered when identifying environmental objectives and the means to achieve them (Page 2011: 53). When applying this principle to CDM projects, we should note that although the CMD Executive Board (EB) has recently prepared propositions which will be deliberated upon at the $19^{\text {th }}$ Conference of Parties (COP) to the UNFCCC, serving as the $9^{\text {th }}$ meeting of the Parties to the Kyoto Protocol (CMP) in November 2013 in Poland, the CMP will conduct the first review of the modalities and procedures for the CDM (UNFCCC 2013). Prior to these 
propositions, no guidelines on procedures for carrying out stakeholder consultations were available (du Monceau and Brohé 2011: 3). Moreover, project developers may be biased in selecting participants for stakeholder consultation and critical views may thus be underrepresented in project reports (Boyd et al. 2009: 826). As already mentioned, Subbarrao and Lloyd (2011: 1606) have found that, although small-scale CDM projects have ensured participation at the local level, the impact level of local stakeholders has not been very significant. In addition, the number of projects that have actually adapted their activities following a stakeholder consultation appears to be extremely limited (du Monceau and Brohé 2011: 10). Stakeholder consultation regarding CDM projects is often only "rudimentary, completely unregulated and badly documented" (Sterk et al. 2009: 18).

Globally, CDM projects are geographically unevenly spread. A mere $1.4 \%$ of projects can be found in Sub-Saharan Africa, while the bulk of projects are located in emerging economies such as China, India and Brazil (Boyd et al. 2009: 821; Bulkeley and Newell 2010; Das 2011: 8; Lloyd and Subarrao 2009: 240; UNFCCC 2012a: 8). In addition, although climate vulnerability is significant in many of the global South's urban environments, less than $1 \%$ of the current CDM projects are located in cities (Hoornweg et al. 2010: 36).

Furthermore, the CDM market appears to favour large, high CER volume projects since small community-based projects are often not economically viable due to the high transaction costs and complex bureaucratic procedures (Lloyd and Subarrao 2009: 240). Indeed, both NGOs and academic researchers have observed that the nature of the approval process excludes civil society: since the PDDs are very technical, they remain virtually inaccessible to local communities (Naughten 2010: 17-8; Newell 2009: 428). Moreover, the extent to which local communities can comment on the CDM projects is highly dependent on structures of local 
governance and opportunities for participation (Boyd et al. 2007: 25). Furthermore, nontechnical considerations and concerns of local communities are rarely addressed or even reflected upon by project developers (Naughten 2010: 17-8). Hence, the supposed beneficiaries rarely have access to the information or expertise required to participate in this highly complex process, nor can they question or challenge the process.

As already mentioned, access to sustainable and affordable energy is key to enable poverty alleviation. However, as argued by Newell and colleagues (2011), the sensitive nature of issues concerning energy supply and access in regional and bilateral agreements, together with the geopolitical and strategic importance of energy, gives rise to a situation in which most countries exercise their right to sovereignty so as to maintain autonomy and control over energy pathways, and few global institutions exercise direct authority over energy resources. Therefore, when regional and bilateral trade and investment agreements are negotiated, which include provisions on energy access and security, the broader public is excluded (Newell et al. 2011: 52-3). Thus, the first criterion of participatory justice, inclusion, does not appear to be met by the CDM in its current form.

\subsection{3..2 Impartiality}

The impartiality criterion implies that policies should be implemented according to preestablished formalities, rules, and procedures. Officials should neither exploit their positions, nor arbitrarily favour particular agents. Furthermore, rules enforced by regulators should be sufficiently consistent and transparent (Page 2011: 54). Flues and colleagues (2008: 2) have found that, although UNFCCC rules on the CDM explicitly state that the CDM Executive Board (EB) meetings should be public (UNFCCC 2006: 38), positions on individual projects 
are exchanged behind closed doors. Although the EB can decide to exclude the public in exceptional cases when deliberating on individual CDM projects, the exceptions have become the rule.

In contrast to the high level of transparency for decisions about methodologies, ${ }^{2}$ the only information available on individual projects is the actual decision (Flues et al. 2008: 6; Nyaoro and Chatterjee 2011: 14). Moreover, while EB members must declare in writing that they have no financial interests in CDM projects, there have been allegations of conflicts of interests (Newell et al. 2011: 41). According to some commentators, EB decisions are highly politicized and subject to intense lobbying, as they tend to favour projects relevant for EB member countries (Flues et al. 2008: 16; Newell 2009: 427). Hence, the criterion of impartiality does not seem to be met.

\subsection{3..3 Equality of Opportunity}

Thirdly, in order to comply with participatory justice, a policy should also reflect norms of 'background fairness'. Referring to examples given by Barry (2002: 98-9), Page says the following about background fairness: "the initial condition of those bound by social policies should be roughly equal in terms of their ability to understand the procedures involved; the experience of the costs of compliance; and the ability to oppose to, or at least express dissatisfaction with the rules, and suggest policy changes" (Page 2011: 54). The equality of opportunity criterion thus implies that all relevant parties should have an equal opportunity to partake in the scheme and reap the benefits thereof.

\footnotetext{
${ }^{2}$ Methodologies provide information that is required in order to determine the amount of CERs generated by a mitigation project activity. By using generic modules, methodological tools are referenced in large-scale and small-scale methodologies in order to determine specific conditions (e.g. additionality of a CDM project activity) or to calculate particular emissions (UNFCCC 2012b: 39-40).
} 
It has been argued that CDM mainly offers end-of-pipe technology solutions and reaps the socalled low hanging fruits (Erion 2005; Gillenwater and Seres 2011: 31; Hepburn 2007: 385; Sihori 2007: 105; Sterk et al. 2009). This is problematic for at least two reasons. First, it is unlikely that end-of-pipe solutions hold a large potential to positively contribute to the local environment, to deliver substantial economic or social benefits (Sterk et al. 2009: 55) or to enhance the climate resilience of the world's poorest communities. Second, if and when mitigation efforts will be widened so as to include non-OECD countries, the future generations of these countries will have to undertake more expensive emission reduction programs themselves, since high-emitting countries will have no economic incentive to buy emission credits from them. Hence, in the future, low-emitting countries will find themselves trying to buy back, at a much higher price, the surplus emissions entitlements which they sold cheaply only 'yesterday' to Annex B countries under the KP or to corporations under the EU ETS (Agarwal, 2002: 384).

In sum, since the CDM in its current form does not meet the criteria of inclusion, impartiality and equality of opportunity, it fails to comply with the requirements of participatory justice.

\section{Policy recommendations for an underachieving CDM}

\subsection{Policy}

According to the KP and EU ETS rules, offsetting should be "supplemental to domestic actions for the purpose of meeting quantified emission limitation and reduction commitments" (UN, 1998: 15; European Parliament and the Council of the EU 2003: 33). In 
the EU ETS, the EU has limited the use of flexibility mechanism credits to no more than 50\% of the emission reductions to be made between 2008 and 2020 (EC 2009: 24). In addition, the EU decided to prohibit the use of CERs from certain industrial gases as of 2013 and intends to move from CDM towards sectoral crediting, particularly in energy-intensive sectors. Furthermore, the EU plans to focus on CDM activity in least-developed countries (Erickson and Lazarus 2011: 2). The EU has declared that the environmental integrity of the CDM should be improved and that a pure offsetting mechanism cannot deliver the emission reductions needed to keep global warming below $2^{\circ} \mathrm{C}^{3}$

The CDM has also put in place more detailed methods and requirements, with new layers of audit and review added, together with increased human resources dedicated to the process. These improvements began to have effect from 2007 onwards. Prior to the revision, the proportion of projects rejected or selected for more rigorous investigation by the CDM Executive Board (EB) was around $10 \%$, while by 2009 it had increased to $61 \%$ (Gillenwater and Seeres 2011: 19; McKinsey \& Company 2009: 3). Furthermore, in line with the decisions under the Kyoto Protocol, the EB has reviewed modalities and procedures for the CDM and has made a number of propositions in light of the review (UNFCCC 2013).

Although various analysts claim that the CDM has the potential to deliver SD and pro-poor benefits, it should be clear from the studies discussed in the previous sections of this paper that the CDM violates the requirements of social and participatory justice. Therefore, following Caney (2010: 218), we would submit that emissions trading can be morally satisfactory only if it either rejects the CDM altogether or if the CDM is radically reformed.

\footnotetext{
${ }^{3}$ http://ec.europa.eu/clima/policies/ets/linking/faq_en.htm
} 
During the years the KP was in place, high-polluting countries relied heavily on the mechanism to comply with reduction targets (OECD/IEA, 2005: 64). It is thus plausible that, when a new emissions abatement treaty is put into effect in 2020, the use of offsetting mechanisms will be high on the agenda again. Furthermore, despite facing difficult challenges to the EU ETS, the voluntary demand for carbon offsets in 2012 grew by $4 \%$, but the market value decreased by $11 \%$, with the European private sector as the largest demand driver (Peters-Stanley \& Yin 2013: 5, 8). There is little doubt that the CDM is in urgent need of reforms if it is to realize its goal of assisting the developing countries to move towards a more sustainable development paradigm. In the following section, without attempting to be exhaustive, we summarize some recommendations that would, in our view, help enable the CDM, or a future version of it, to fulfil that goal.

\subsection{Proposed measures}

\subsubsection{Social Justice}

In Crowe's analysis of 114 CDM projects, twenty-five of these projects had a premium addon standard such as the Gold Standard ${ }^{4}$ or the Social Carbon methodology and the Climate, Community \& Biodiversity Standard (CCBS) (Crowe 2013). These add-on standards concern a stringent and transparent set of criteria with which project developers need to comply, thereby shaping and constituting the 'rules of the game' by which participants abide, for the standards provide incentives and disincentives to behave in particular ways (Newell 2009:

\footnotetext{
${ }^{4}$ The Gold Standard (GS), for example, was established in 2003 by a consortium of NGOs and only allows renewable energy and end-use energy efficiency projects. To obtain the GS, project developers need to answer eleven question concerning human development issues. These questions cover human rights, resettlement, removal of cultural heritage, freedom of association, compulsory labour, child labour, discrimination, healthy work environment, precautionary approach in regard to environmental challenges, degradation of critical natural habitats, corruption (Sterk et al. 2009: 7). In addition, project developers submit a sustainability monitoring plan which is used to verify ex post whether the project has indeed contributed to SD as assessed ex ante (Sterk et al. 2009: 16). See also http://www.cdmgoldstandard.org/
} 
430). Research indicates that projects certified with the Gold Standard generally capture greater SD benefits than is the case for CDM projects without add-on standards (Killick 2012: 21). Crowe's results show that $64 \%$ of the projects with add-on standards delivered pro-poor benefits, while $36 \%$ did not, leading to the conclusion that projects with premium add-on standards may, overall, perform better than regular CDM projects (Crowe 2013: 69).

Although Crowe (2013: 69) and Sihori (2007: 101-2) have found that the development of renewable energy projects does not prima facie outperform other project categories in delivering pro-poor benefits, their results lend support to the conclusion that communitybased, small scale, renewable energy projects hold more potential for the delivery of pro-poor benefits than large scale projects (Brunt and Knechtel 2005; Subbarao and Lloyd 2011: 16012). However, although rural energy provision projects are particularly positive in contributing to human development and thus sustainable development, they are rare in the CDM pipeline (Boyd et al. 2009: 822; Subbarao and Lloyd 2011: 1602). Since CDM projects are seldom found amongst the poorest, a regionally balanced growth of CDM projects needs to be incentivized. Hence, in the absence of private CDM projects in regions with a high poverty incidence, public sector entities should set up CDM projects in these areas, especially those pertaining to renewable energy and the agricultural sector (Newell et al. 2009: 9; Sihori 2007: 106). Alternatively, premium prices or add-on standard validation should be granted to CERs from CDM renewable energy projects located in regions with a high poverty incidence.

Since CERs with add-on standards outperform conventional CERs in delivering pro-poor benefits, a tax could be raised on the trade of the latter, with revenues funding local development projects. Such a tax would be analogous to a Tobin tax (Ott and Sachs 2000: 19). The Chinese government, for example, raises taxes on HFC CDM projects with revenues 
flowing to a 'CDM Fund', which is supposed to finance renewable energy projects (Bozmoski et al. 2008: 27; Fuhr and Lederer 2009: 338; Newell 2009: 427). A tax on conventional CERs could possibly outbalance the surplus cost of CERs with add-on standards, which are generally sold at about $25 \%$ above the market value for normal CERs (Bulkeley and Newell 2010: 97).

In addition, propositions have been made to apply a discount rate to CERs (du Monceau and Brohé 2011: 17; Castro and Michaelowa 2010; Schneider 2008; Sterk et al. 2009: 22, 31). Although this proposition intends to ensure that the CDM delivers de facto emission reductions, it can also be applied to discriminate against conventional CERs in favour of CERs with add-on standards. The latter would then be exempted from the discount rate. When discounting CDM emission reductions, not all reductions generated by a project enter the carbon market, meaning that part of the emission reduction is not used to offset emissions elsewhere, but to provide real global emission reductions (Castro and Michaelowa 2011: 5). Discounting CDM emission reductions without add-on standards could potentially redirect the mechanism towards the poorer developing countries, as discount rates can be tied to the level of development of the host country. Discounting emission reductions would then be in line with the CDM objective of assisting developing countries in progressing towards SD (Castro and Michaelowa 2010: 6-7). This could create an increased demand for CERs with add-on standards, which would result in a premium price for CERs from projects with a strong contribution to $\mathrm{SD}$, which in turn might increase the share of these projects in the carbon market (Sutter and Parreño 2007: 89).

Furthermore, CDM projects that focus on building climate resilience in poor regions, be they rural or urban, could be awarded with add-on standards. While adaptation focuses on singular 
risk factors, resilience addresses the overall performance of a region and the reliability and efficiency of an asset's or location's performance under a wide range of circumstances (Brugmann 2012: 217). Regarding energy, governments need to implement policy frameworks that help overcome the barriers across different sectors of the economy, in order to help vulnerable regions address risks by developing an integrated approach to conventional development planning, project design and development regulation (IEA 2013: 97; Brugmann 2012: 231).

The most fundamental CDM reform needed, however, is the development of more specific SD criteria. Currently, few procedures exist to ensure that projects produce social and environmental SD benefits (Gillenwater and Seres 2011: 30). Moreover, a clear and globally accepted definition of SD is unlikely to be accepted since developing countries consider such a definition to be an infringement of their sovereignty (Olsen 2007: 61). Nevertheless, we would argue that existing and prominent definitions of SD - such as those by the Rio Declaration (UNCED 1992, Principle 3) and the Brundtland Commission (WCED 1987, 54) can function as guidelines to the development of SD criteria for CDM projects. ${ }^{5}$ Unless national leaders agree on minimum standards for SD indicators, the CDM mechanism will remain flawed. A possible remediation, which has been suggested by several commentators, would be to adopt a 'do no harm' approach that would include agreed quantitative SD indicators. Any improvement upon the baseline could be left to the host country's decision, thereby respecting its national sovereignty (du Monceau and Brohé 2011: 16-7; Killick 2012: 22; Sterk et al. 2009: 222).

\footnotetext{
${ }^{5}$ Despite persisting discussions about the definition of SD, there is a body of global agreements related to SD that have been reached at the UN level (see NGO Committee on Education, n.d.).
} 
Furthermore, in the absence of a national, regional or global agreement on what SD should include, entities such as the EU could introduce their own additional requirements for importing CERs into the EU ETS (Sterk et al. 2009: 23) or, alternatively, they could further limit the quantity of CERs a party can use (Caney 2010: 218). National CDM Authorities should require project developers to present a clearer exposition of social sustainability and development input of their projects (Sihori 2007: 106). In addition, the criteria that host countries employ to evaluate whether a project may generate CERs should be tightened. For example, CERs could only be granted to projects using non-fossil fuels (Caney 2010: 218). Projects that would then be able to demonstrate the desired SD input of their projects could be rewarded in the form of add-on standard validation of their projects (Sihori 2007: 106).

Regarding the add-on standards, since the Gold Standard (GS) focuses primarily on renewable energy and end-use energy efficiency projects (Sterk et al. 2009: 14), Crowe suggests the development of a new and revised premium add-on standard which would incorporate a number of key characteristics, so as to offer a pathway to more CDM projects actualizing their potential to both deliver individual pro-poor benefits and to contribute to poverty alleviation. Such characteristics would include a focus on projects at the community and household level, located in the Least Developed Countries (LDCs) and areas of high poverty (Crowe 2013: 76). Although the GS demands comprehensive stakeholder participation (Sterk et al. 2009: 20), this focus should be complemented with a combination of specific pro-poor criteria (Crowe 2013: 76). According to Crowe's (2013: 76) survey results, a strong demand exists on the carbon market for CERs with pro-poor benefits attached. Hence there is a good market potential for an explicitly labelled pro-poor CDM add-on standard.

\subsubsection{Participatory Justice}


Since, as explained earlier, the CDM fails to meet the requirements of participatory justice, adjustments to its governance and project cycle process are necessary. However, few of the problems we have listed can be addressed through ad hoc remedies. No matter how carefully the CDM governance were to be redesigned, it would remain unable to overcome or compensate for governance deficits at the national and subnational level in terms of accountability, transparency, and legitimacy (Newell 2009: 432). In addition, the lack of capacity within the EB is in many ways matched by a lack of capacity at the national level among authorities responsible for registering and monitoring CDM projects (Boyd et al. 2007: 27; Newell et al. 2009: 12). Nevertheless, one possible ad hoc solution would be to introduce mechanisms that commit ex post validation of the PDD's claims before a project is granted approval (Nyaoro and Chatterjee 2011: 25).

Another short-term fix would be for the CDM Executive Board to (re)consider the quality thresholds applied by a Designated Operational Entity (DOE, i.e. entities that evaluate whether a project is eligible for the CDM) when deciding on registration and issuance (Nyaoro and Chatterjee 2011: 23). In the propositions made by the CDM Executive Board to the $9^{\text {th }}$ meeting of Parties to the Kyoto Protocol the EB has indeed recommended that the rules on accreditation should include principles that the Board must apply to elaborate and enforce the standards for DOEs. These principles should include consistency, impartiality, transparency and confidentiality, rigour, competence, and openness and accessibility (UNFCCC 2013: 7). Furthermore, regarding stakeholder consultation, the EB has proposed to mandate the DOEs to validate whether local stakeholder consultation was carried out in accordance with host country laws and regulation, "and to evaluate how the content of the comments was duly taken into account" (UNFCCC 2013: 8). Although these propositions are 
a step forward, they are still rather vague and offer little guidance on implementation. Moreover, the latter proposition leaves the extent and depth of the stakeholder consultation to the host countries' initiative.

Since public participation in the CDM's decision making is currently limited, one of the most promising long-term adjustments would be to increase cooperation between private and public sectors, in other words, to involve business, NGOs, and civil and academic society in the CDM decision-making process. However, adjustments would need to take into account the diverse local or regional political situations. In India, for example, NGOs and civil society do not function as a watchdog of the CDM but rather as a partner, directly participating in and promoting CDM activities. In Brazil, having established procedures for public consultation, several universities offer courses in CDM project development, whereas in China public participation in decision-making is limited and NGOs abstain from critically commenting on CDM projects (Fuhr and Lederer 2009: 336; Newell 2009: 433).

A new add-on standard, as advocated by Crowe (2013), could require projects to take stakeholder consultation seriously by verifying ex post the ex ante claims made in the PDDs concerning possible local concerns/participation/benefits. Although such verification would be difficult to operationalize, an additional set of modalities and procedures could outline detailed requirements for stakeholder involvement, including who to involve, how to communicate and contact stakeholders, how often and in whose presence consultations need to take place, and how to present the project in a non-technical manner and appropriate local language (Sterk et al. 2009: 23). In light of these requirements a 'global checklist' could be created which would need to be respected by project developers. Nevertheless, local stakeholder involvement may face problems such as, inter alia, a lack of discussion culture in 
the host country or local residents perceiving the presence of local officials as intimidating (Sterk et al. 2009: 15). Such potential obstacles are not addressed by the EB's proposition.

Although NGOs are hardly able to ensure quality assurance, as they lack the capacity to look into specific projects, collaboration between NGOs, civil and academic society and business could address this lacuna. NGOs and civil society could be called upon to help verify whether the global checklist criteria are met which would enable project developers to better recognise community needs (Newell et al. 2009: 14; Streck 2004: 312). Furthermore, NGOs could mobilize stakeholder participation and help prioritize CDM mitigation options, capacity building activities, and policy measures (Streck 2004: 312). Investors would benefit, for the financial risk would be reduced since the projects would enjoy local support and would thus avoid political opposition, legal action and local unrest (Streck 2004: 311-2; Newell et al. 2009: 15). Furthermore, business could be awarded with add-on standard CERs not prone to discounting. Serving as a best practice example, intense collaboration between the academic world, NGOs and policy makers already characterises the 'climate change scene' in Brazil (Newell et al. 2009: 12).

Last but not least, a 'grievance mechanism' should be built-in during the implementation phase. If valid grievances are not addressed appropriately or if the quality of the CERs cannot be assured, the project should no longer receive CERs or should lose its add-on standard qualification (Sterk et al. 2009: 29). When groups of countries start demanding the application of additional sets of modalities and procedures for importing CERs into their emissions trading systems, CERs with add-on standards delivering pro poor benefits and intensive stakeholder consultation will become increasingly appealing. 


\section{Conclusion}

While the UN and EU have adopted the maximum $2{ }^{\circ} \mathrm{C}$ rise principle in their climate policies, research indicates that a $4^{\circ} \mathrm{C}$ rise is more likely. Furthermore, although climate change hits the poorest hardest, the flows of adaptation finance do not meet the current needs. The CDM is an offsetting market-based mechanism that delivers CERs to those investing in emission abatement in developing countries. Although the EU ETS is the only large emission trading system in which CERs are traded, the system has become terminally flawed as a result of design issues and oversupply of entitlements and CERs. We have conducted an extensive review of the relevant literature and found that the CDM is not fulfilling its second core objective, i.e. assisting developing countries to reach sustainable development. Starting from the assumption that sustainable development should include human development, we have analysed whether the CDM delivers pro-poor benefits to host country communities in accordance with principles of social and participatory justice. We found that the CDM falls short in both respects, prompting the conclusion that the mechanism should either be strengthened or abolished. Finally, we have discussed a variety of policy recommendations that would enable the CDM, or a future version of it, to fulfil its formidable task of helping the worst-off. Even if climate policy tools achieve emissions reductions, a failure to support those most victimized by a problem they are not responsible for, renders any policy unjust and morally reprehensible and thus in need of fundamental rethinking.

\section{Acknowledgments}

Blinded for the purposes of peer review (to be added later).

\section{References}


Agarwal, A., 2002, A southern perspective on curbing global climate change. Climate change policy: A survey, S. Schneider, A. Rosencranz, \& J. O. Niles (eds.). Island Press, Washington, DC, USA. 373-392. Retrieved from http://stephenschneider.stanford.edu/Publications/PDF_Papers/14-Ch14(373-392).pdf

Arnell, N.W., Lowe, J.A., Brown, S., Gosling, S.N., Gottschalk, P., Hinkel, J., Lloyd-Hughes, B., Nicholls, R.J., Osborn, T.J., Osborne, T.M., Rose, G.A., Smith, P., Warren, R.F., 2013. A global assessment of the effects of climate policy on the impacts of climate change. Nature Climate Change . DOI: 10,1038/NCLIMATE1793.

Barry, B. (2002) Political Argument: A Reissue with a New Introduction. University of California Press, Berkeley, USA.

Betts, R., Collins, M., Hemming, D., Jones, C., Lowe, J., \& Sanderson, M., 2011. When could global warming reach $4{ }^{\circ} \mathrm{C}$ ?. Philosophical Transactions of the Royal Society A, 369. 67-84.

Biermann, F., 2012. Planetary boundaries and earth system governance - Exploring the links. Ecological Economics , 81.4-9.

Boyd, E., Hultman, N.E., Roberts, J.T., Corbera, E., Cole, J., Bozmoski, A., Ebeling, J., Tippman, R., Mann, P., Brown, K., Liverman, D.M., 2009. Reforming the CDM for sustainable development: lessons learned and policy futures. Environmental Science \& Policy , 12. 820-831. Retrieved from http://www.environment.arizona.edu/files/env/profiles/liverman/boyd-et-al-esp-20090.pdf

Boyd, E., Hultman, N.E., Roberts, T., Corbera, E., Ebeling, J., Liverman, D.M., Brown, K., Tippman, R., Cole, J., Mann, P., Kaiser, M., Robbins, M., Bumpus, A., Shaw, A., Ferreira, E., Bozmoski, A., Villiers, C., Avis, J., 2007. The Clean Development Mechanism: An assessment of current practice and future approaches for policy. Tyndall Working Paper No. 114, Tyndall Centre for Climate Change Research, Norwich. Retrieved from http://www.tyndall.ac.uk/sites/default/files/wp114.pdf

Bozmoski, A., Lemos, M.A., Boyd, E., 2008. Prosperous Negligence. Governing the Clean Development Mechanism for markets and development. Environment , 50(3). 18-30.

Burgmann, J. , 2012. Financing the resilient city. Environment and Urbanization, 24(1). 215232. DOI $10.117 / 0956247812437130$

Buchner, B. Falconer, A., Hervé-Mignucci, M; Trabacchi, C., Brinkman, M., 2011. The Landscape of Climate Finance. Climate Policy Initiative, Venice, Italy. Retrieved from http://climatepolicyinitiative.org/wp-content/uploads/2011/10/The-Landscape-of-ClimateFinance-120120.pdf

Brunt, C., Knechtel, A., 2005. Delivering Sustainable Development Benefits Through the Clean Development Mechanism. The Pembina Institute, Canada. Retrieved from http://www.pembina.org/pub/207

Bulkeley, H., \& Newell, P., 2010. Governing climate change. Routledge, London.

Caney, S., 2010. Markets, morality and climate change: What, if anything, is wrong with 
emissions trading? New Political Economy, 15(2). 197-224.

Castro, P., Michaelowa, A., 2010. The impact of discounting emission credits on the competitiveness of different CDM host countries. Ecological Economics, 70(1). 34-42. Retrieved from http://dx.doi.org/10.1016/j.ecolecon.2010.03.022

Costello, A., Abbas, M., Allen, A., Ball, S. Bell, S., Bellamy, R., Friel, S., Groce, N., Johnson, A., Kett, M., Lee, M., Levy, C., Maslin, M., McCoy, D., McGuire, B., Montgomery, H., Napier, D., Pagel, C., Patel, J., Puppim de Oliveira, J.A., Redclift, N., Rees, H., Rogger, D., Scott, J., Stephenson, J., Twigg, J., Wolff, J., Patterson, C., 2009. Managing the health effects of climate change. The Lancet, 373. 1693-1733.

Crowe, T.L., 2013. The potential of the CDM to deliver pro-poor benefits. Climate Policy, 13(1). 58-79.

Das, K., 2011. Technology Transfer under de Clean Development Mechanism: an empirical study of 1000 CDM projects. The Governance of Clean Development Working Paper 14. School of International Development, University of East Anglia, Norwich, UK. Retrieved from http://www.uea.ac.uk/international-development/research/gcd/Das+2011

den Elzen, M.G.J., Mendoza-Beltran, A., Hof, A.F., van Ruijven, B., van Vliet, J., 2013. Reduction targets and abatement costs of developing countries resulting from global and developed countries' reduction targets in 2050. Mitigation and Adaptation Strategies for Global Change, 18(4). 291-512.

Dirix, J., Peeters, W., Eyckmans, J., Jones, P.T., Sterckx, S., 2013. Strengthening bottom-up and top-down climate governance. Climate Policy, 13(3). 363 - 383.

Djanibekov, U., Khamzina, A., Djanibekov, N., Lamers, J., 2012. How attractive are shortterm CDM forestations in arid regions? The case of irrigated croplands in Uzbekistan. Forest Policy and Economics , 21. 108-117.

du Monceau, T., Brohé, A., 2011. Sustainable Development and Social Equity. Briefing paper, AEA, energy and climate change consultancy, London, UK. Retrieved from http://ec.europa.eu/clima/policies/ets/linking/docs/sustainable_development_en.pdf

EC, 2013. Commissioner Hedegaard's statement on today's vote by the European Parliament on the backloading proposal. European Commission Memo, Brussels, Belgium. Retrieved from http://europa.eu/rapid/press-release_MEMO-13-343_en.htm

EC, 2009. EU action against climate change. The EU Emissions Trading Scheme. European Commission, Brussels, Belgium. Retrieved from http://ec.europa.eu/clima/publications/docs/ets_en.pdf

EC, 2007. Combating climate change: The EU leads the way. European Commission, Brussels, Belgium. Retrieved from http://ec.europa.eu/europeaid/infopoint/publications/communication/10g_en.htm

Erickson, P., Lazarus, M., 2011. Implications of International Greenhouse Gas Offsets on Global Climate Mitigation, Working Paper WP-US-1106, Stockholm Environmental Institute, 
USA. Retrieved from http://sei-us.org/Publications_PDF/SEI-WorkingPaperUS-1106.pdf

Erion, G., 2005. Low Hanging Fruit Always Rots First. Observations from South Africa's Crony Carbon Market. Center for Civil Society, University of KwaZulu-Natal, Durban, South-Africa. Retrieved from http://www.carbontradewatch.org/pubs/CDMsouthafrica.pdf

EU ETS at a crossroads, 2013. EU ETS at a crossroads: recalibrating an oversupplied market to spur investments and innovation. Climate Action Network, Sandbag, World Wildlife Fund, Greenpeace. Briefing. Retrieved from http://www.sandbag.org.uk/site_media/pdfs/reports/EU_ETS_at_a_craossroads_NGO_briefin g_01.2013_FINAL.pdf

European Parliament and the Council of the EU, 2003. Directive 2003/87/EC of the European Parliament and the Council of 13 October 2003 establishing a scheme for greenhouse gas emission allowance trading within the Community and amending Council Directive 96/61/EC. Official Journal of the European Union, L 275. 32-46.

Flues, F., Michaelowa, A., Michaelowa, K., 2008. UN approval of greenhouse gas emission reduction projects in developing countries: The Political economy of the CDM Executive Board. University of Zurich and Center for International and Comparative Studies (CIS), Zurich, Switzerland. Retrieved from http://www.cis.ethz.ch/events/past_events/PEIO2008/Flues.Dreher.Michaelowa_UN.GHG.Re duction

Fuhr, H., Lederer, M., 2009. Varieties of Carbon Governance in Newly Industrializing Countries. The Journal of Environmental Development , 18. 327-345. Retrieved from http://jed.sagepub.com/content/18/4/327

GHF, 2009. The Anatomy of A Silent Crisis. Global Humanitarian Forum, Geneva, Switzerland. Retrieved from http://www.ghf-ge.org/human-impact-report.pdf

Gillenwater, M., Seres, S., 2011. The Clean Development Mechanism, a review of the first international offset program. PEW Center on Global Climate Change, USA. Retrieved from http://www.c2es.org/docUploads/clean-development-mechanism-review-of-firstinternational-offset-program.pdf

Griggs, D., Stafford-Smith, M., Gaffney, O., Rockstöm, J., Öhmann, M.C., Shyamsundar, P., Steffen, W., Glaser, G., Kanie, N., Noble, I., 2013. Sustainable development goals for people and planet. Nature, 495. 305-307.

Grubb, M., 2013. Doha’s Dawn? Climate Policy, 13(3). 281-284.

Hansen, J., Ruedy, R., Sato, M., 2010. Global surface temperature change. Reviews of Geophysics , 48(RG4004). DOI: 10.1029/2010RG000345.

Hepburn, C., 2007. Carbon Trading: A Review of the Kyoto Mechanisms. Annual Review of Environment and Resources, 32. 375-393.

Hoornweg, D., Sugar, L., Freire, M., Anderson, C., Bhada, P., Trejos, C.L., Dave, R., Lee, M., 2010. Cities and Climate Change: An Urgent Agenda. World Bank, Washington, DC, 
USA. Retrieved from http://siteresources.worldbank.org/INTUWM/Resources/3402321205330656272/CitiesandClimateChange.pdf

Huhtale, A., Curto, S., Ambrosi, P., 2010. Monitoring Climate Finance and ODA. May 2010 Issues Brief \#1. World bank, Washington, DC, USA. Retrieved from http://climatechange.worldbank.org/sites/default/files/documents/DCFIB\%231-webJune15.pdf

IEA, 2013. Redrawing the Energy-Climate Map. International Energy Agency, Paris, France. Retrieved from http://www.worldenergyoutlook.org/media/weowebsite/2013/energyclimatemap/RedrawingE nergyClimateMap.pdf

IDMC, 2013. Global Estimates 2012. People displaced by disasters. Internal Displacement Monitoring Centre, Switzerland. Retrieved from http://www.internaldisplacement.org/publications/global-estimates-2012

IPCC, 2012. Managing the Risks of Extreme Events and Disasters to Advance Climate Change Adaptation. Intergovernmental Panel on Climate Change, Switzerland. Retrieved from http://ipcc-wg2.gov/SREX/

IPCC, 2007. Climate Change 2007: Synthesis Report. Intergovernmental Panel on Climate Change. Geneva, Switzerland. Retrieved from http://www.ipcc.ch/pdf/assessmentreport/ar4/syr/ar4_syr.pdf

Killick, R., 2012. Exploring the measurement of sustainable development in the Clean Development Mechanism (CDM). The Governance of Clean Development Working Paper 19. School of International Development, University of East Anglia, Norwich, UK. Retrieved from http://www.tyndall.ac.uk/sites/default/files/gcd_working_paper_019_-_killick_2012.pdf

Le Quéré, C., Raupach, M., Canadell, J.,, Marland, G., 2009. Trends in the sources and sinks of carbon dioxide. Nature Geoscience , 2. 831-836.

Lloyd, B., Subbarao, S., 2009. Development challenges under the Clean Development Mechanism (CDM) - can renewable energy initiatives be put in place before peak oil? Energy Policy, 37. 237-245.

Mattsson, E., Ostwald, M., Nissanka, S.P., Holmer, B., Palm, M., 2009. Recovery and protection of coastal ecosystems after tsunami event and potential for participatory forestry CDM - Examples from Sri Lanka. Ocean \& Coastal Management, 52. 1-9.

McKinsey and Company (2008) Helping the UNFCCC secretariat improve its support to the Clean Development Mechanism and Joint Implementation. An independent technical review by McKinsey \& Company. Retrieved from http://cdm.unfccc.int/workshops/cop15/COP15_SE_091208_SDM_imp_TechRev.pdf

Meinshausen, M., Meinshausen, N., Hare, W., Raper, S.C.B., Frieler, K., Knutti, R., Frame, D.J., Allen, M.R., 2009. Greenhouse-gas emission targets for limiting global warming to $2^{\circ} \mathrm{C}$. Nature , 458. 1158-1163. 
Michaelowa, A., Michaelowa, K., 2007. Does climate policy promote development? Climatic Change, 84. 1-4.

Naughten, A., 2010. Designed to fail? The concepts, practices and controversies behind carbon trading. FERN, Brussels. Retrieved from http://www.fern.org/sites/fern.org/files/FERN_designedtofail_internet_0.pdf

Neumayer, E., 2013. Human Development and Sustainability. Journal of Human Development and Capabilities , 13(4). 561-579.

Neumayer, E., 2010. Human development and sustainability. Human development research paper 2010/05. UNDP, United Nations Development Programme, New York, USA. Retrieved from http://hdr.undp.org/en/reports/global/hdr2010/papers/HDRP_2010_05.pdf

Newell, P., 2009. Varieties of CDM Governance: Some Reflections. The Journal of Environment Development, 18(4). 425-435.

Newell, P., Jenner, N., Baker, L., 2009. Governing Clean Development: A Framework for Analysis. The Governance of Clean Development Working Paper 001. Overseas Development Group, University of East Anglia, Norwich, UK. Retrieved from http://www.tyndall.ac.uk/sites/default/files/GCD_WorkingPaper001.pdf

Newell, P., Phillips, J., Mulvaney, D., 2011. Pursuing Clean Energy Equitably. Human Development Research paper 2011/03. UNDP, United Nations Development Programme, New York, USA. Retrieved from http://hdr.undp.org/fr/rapports/mondial/rdh2011/documents/HDRP_2011_03.pdf

NGO Committee on Education (n.d.) UN Documents: Gathering a body of global agreements. http://www.un-documents.net/k-001303.htm

Nyaoro, J., Chatterjee, B., 2011. Governance of the Clean Development Mechanism. Study on the Integrity of the Clean Development Mechanism. Briefing paper. AEA, energy and climate change consultancy, London, UK. Retrieved from

http://ec.europa.eu/clima/policies/ets/linking/docs/governance_en.pdf

OECD/IEA, 2005. Act locally, trade globally. Organisation for Economic Cooperation and Development/ International Energy Agency, Paris, France. Retrieved from http://www.iea.org/publications/freepublications/publication/act_locally-1.pdf

Olsen, K.H., 2007. The clean development mechanism's contribution to sustainable development: a review of the literature. Climatic Change , 84, 59-73.

Ott, H.E., Sachs, W., 2000. Ethical Aspects of Emissions Trading. Wuppertal Papers Nr. 110. Contribution to the World Council of Churches Consultation on 'Equity and Emissions Trading - Ethical and Theological Dimensions', May 9-14, Saskatoon, Canada. Retrieved from http://www.studver.unimaas.nl/critics/literature/WP110\%20ET\%20ethics.pdf

Page, E., 2011. Cosmopolitanism, climate change, and greenhouse emissions trading. International Theory, 3(1). 37-69. 
Peeters, W., Dirix, J., Sterckx, S., 2013. Putting sustainability into Sustainable Human Development. Journal of Human Development and Capabilities , 14(1). 58-76.

Peters, G.P., Andrew, R.M., Boden, T., Canadell, J.G., Ciais, P., Le Quéré, C., Marland, G., Raupach, M.R., Wilson, C., 2013. The challenge to keep global warming below $2^{\circ} \mathrm{C}$. Nature Climate Change, 3. 4-6.

Peters, G.P., Marland, G., Le Quéré, C., Boden, T., Canadell, J.G., Raupach, M.R., 2012. Rapid growth in $\mathrm{CO}_{2}$ emissions after the 2008-2009 global financial crisis. Nature Climate Change , 2. 2-4.

Peters, G., Minx, J., Weber, C., Edenhofer, O., 2009. Growth in emissions transfers via international trade from 1990 to 2008. Proceedings of the National Academy of Sciences of the USA , 108(21). 8903-8908.

Peters-Stanley, M., Yin, D., 2013. Maneuvering the Mosaic - State of the Voluntary Carbon Markes 2013, Executive Summary. Forest Trends' Ecosystem Marketplace \& Bloomberg New Energy Finance, USA. Retrieved from http://www.foresttrends.org/vcm2013.php\#coming_soon

Pointcarbon, 2013, February 19. Backloading clears first hurdle but uncertainty still remains. Retrieved from http://www.pointcarbon.com/aboutus/pressroom/pressreleases/1.2189320

Reuters, 2013, February 19. EU Parliament hesitates in drafting law for $\mathrm{CO}_{2}$ fix. Retrieved from http://www.reuters.com/article/2013/02/19/us-eu-ets-idUSBRE91I0H320130219

Rogelj, J., McCollum, D., Reisinger, A., Meinshausen, M., Riahi, K., 2013a. Probabilistic cost estimates for climate change mitigation. Nature , 493. 79-83.

Rogelj, J., McCollum, D.L., Riahi, K., 2013b. The UN's 'Sustainable Energy for All' initiative is compatible with a warming limit of $2^{\circ} \mathrm{C}$. Nature Climate Change , 3. 545-551.

Rogelj, J., McCollum, D.L., O’Neill, B.C., Riahi, K., 2012. 2020 emissions levels required to limit warming to below $2^{\circ} \mathrm{C}$. Nature Climate Change , 3. 405-412.

Rogelj, J., Hare, W., Lowe, J., van Vuuren, D.P., Riahi, K., Matthews, B., Hanaoka, T., Jiang, K., Meinshausen, M. (2011) Emission pathways consistent with a $2^{\circ} \mathrm{C}$ global temperature limit. DOI: 10.1038/NCLIMATE1258.

Sandbag, 2013, May 2. Surge in offsets threatens to overwhelm EU's troubled carbon market. Retrieved from http://www.sandbag.org.uk/blog/2013/may/2/surge-offsets-threatensoverwhelm-eus-troubled-car/

Schneider, L., 2008. A Clean Development Mechanism (CDM) with atmospheric benefits for a post-2012 climate regime, Discussion Paper, Öko-Institut, Berlin, Germany. Retrieved from http://www.oeko.de/oekodoc/779/2008-227-en.pdf

Schneider, L., Grashof, K., 2007. Capacity Development for the Clean Development Mechanism. Lessons Learned in Ghana, India, Indonesia, South Africa. GTZ Climate Protection Programme \& Federal Ministry for Economic Cooperation and Development 
Germany, Öko-Institut, Berlin, Germany. Retrieved from

http://www.oeko.de/oekodoc/577/2006-135-en.pdf

Sihori, S., 2007. CDM: Is it a 'win-win' strategy for rural poverty alleviation in India?

Climatic Change, 84. 91-110.

Sterk, W., Rudolph, F., Arens, C., Eichhorst, U., Kiyar, D., Wang-Helmreich, H., Swiderski, M., 2009. Further Development of the Project-Based Mechanisms in a Post-2012 Regime.

Final Report of the project Commissioned by the German Federal Ministry for the

Environment, Nature Conservation and Nuclear Safety. Wuppertal Institute for Climate,

Environment and Energy, Germany. Retrieved from

http://wupperinst.org/uploads/tx_wupperinst/CDM_Post_2012_Study.pdf

Streck, C., 2004. New partnerships in Global Environmental Policy: The Clean Development Mechanism. Journal of Environment \& Development , 13(3). 295-322. Retrieved from http://www.gppi.net/fileadmin/gppi/New_Partnerships_Streck.pdf

Subbarao, S., Lloyd, B., 2011. Can the Clean Development Mechanism (CDM) deliver? Energy Policy, 39. 1600-1611.

Sutter, C., Parreño, J.C., 2007. Does the current Clean Development Mechanism (CDM) deliver its sustainable development claim? An analysis of officially registered CDM projects. Climatic Change, 84. 75-90.

Tyler, S., Moench, M., 2012. A framework for urban climate resilience. Climate and Development , 4(4). 311-326.

UN, 2012a. Resolution adopted by the General Assembly: The future we want (A/RES/55/288). United Nations, New York. Retrieved from http://www.un.org/ga/search/view_doc.asp?symbol=A/RES/66/288\&Lang=E

UN, 2012b. Sustainable Energy for All, A Global Action Agenda. United Nations, New York. Retrieved from http://www.sustainableenergyforall.org/images/content/SE4ALLActionAgenda.pdf

UN, 1998. Kyoto Protocol to the United Nations framework convention on climate change. United Nations, New York. Retrieved from http://unfccc.int/resource/docs/convkp/kpeng.pdf

UNCED, 1992. The Rio Declaration on Environment and Development. United Nations Conference on Environment and Development. Retrieved from http://www.unesco.org/education/nfsunesco/pdf/RIO_E.PDF

UNDP, 2013. Human Development Report 2013. The Rise of the South: Human Progress in a Diverse World. United Nations Development Programme, New York, USA. Retrieved from http://hdr.undp.org/en/reports/global/hdr2013/

UNEP, 2012. The Emissions Gap Report 2012. United Nations Environmental Programme, Nairobi. Retrieved from www.unep.org/publications/ebooks/emissionsgap2012/ 
UNFCCC, 2013. Recommendations of the Executive Board of the clean development mechanism on possible changes to the modalities and procedures of the clean development mechanism (FCCC/SBI/2013/INF.1). United nations Framework Convention on Climate Change. United Nations Climate Change Secretariat, Germany. Retrieved from http://unfccc.int/documentation/documents/advanced_search/items/6911.php?priref $=6000073$ $\underline{62}$

UNFCCC, 2012a. Benefits from the CDM. United Nations Framework Convention on Climate Change. United Nations Climate Change Secretariat, Germany. Retrieved from http://cdm.unfccc.int/about/dev_ben/index.html

UNFCCC, 2012b. CDM Methodology Booklet. United Nations Framework Convention on Climate Change. United Nations Climate Change Secretariat, Germany. Retrieved from https://cdm.unfccc.int/methodologies/

UNFCCC, 2011. Report of the Conference of the Parties serving as the meeting of the Parties to the Kyoto Protocol on its seventh session, held in Durban from 28 November to 11 December 2011. Part One: Proceedings (FCCC/KP/CMP/ 2011/10). United Nations Framework Convention on Climate Change Secretariat, Germany. Retrieved from http://unfccc.int/resource/docs/2011/cmp7/eng/10.pdf

UNFCCC, 2006. Report of the Conference of the Parties serving as the meeting of the Parties to the Kyoto Protocol on its first session, held at Montréal from 28 November to 10 December 2005. Addendum. Part Two: Action taken by the Conference of the Parties serving as the meeting of the parties to the Kyoto Protocol at its first session

(FCCC/KP/CMP/2005/8/Add.2). United Nations Framework Convention on Climate Change Secretariat, Germany. Retrieved from

http://unfccc.int/resource/docs/2005/cmp1/eng/08a02.pdf

UNFCCC, 2001. Report of the Conference of the Parties on its Seventh Session, held at Marrakesh from 29 October to 10 November 2001. Part One: Proceedings (FCCC/CP/2001/13). United Nations Framework Convention on Climate Change Secretariat, Germany. Retrieved from http://unfccc.int/resource/docs/cop7/13.pdf

van Vuuren, D., den Elzen, M., van Vliet, J., Kram, T., Lucas, P., \& Isaac, M., 2009. Comparison of different climate regimes: The impact of broadening participation. Energy Policy, 37. 5351-5362.

WCED, 1987. Our Common Future. Brundtland Report. World Commission on Environment and Development, New York, Oxford University Press. Retrieved from http://conspect.nl/pdf/Our_Common_Future-Brundtland_Report_1987.pdf

World Bank/IEA, 2013. Global Tracking Framework. World Bank and the International Energy Agency, Washington, USA and Paris, France. Retrieved from http://www.iea.org/publications/freepublications/publication/name,38535,en.html 
